\title{
WestVirginiaUniversity
}

THE RESEARCH REPOSITORY @ WVU

Graduate Theses, Dissertations, and Problem Reports

2019

\section{A Timeless Ritual}

Luke Thomas Doyle

West Virginia University, Itd0005@mix.wvu.edu

Follow this and additional works at: https://researchrepository.wvu.edu/etd

Part of the Ceramic Arts Commons

\section{Recommended Citation}

Doyle, Luke Thomas, "A Timeless Ritual" (2019). Graduate Theses, Dissertations, and Problem Reports. 3784.

https://researchrepository.wvu.edu/etd/3784

This Thesis is protected by copyright and/or related rights. It has been brought to you by the The Research Repository @ WVU with permission from the rights-holder(s). You are free to use this Thesis in any way that is permitted by the copyright and related rights legislation that applies to your use. For other uses you must obtain permission from the rights-holder(s) directly, unless additional rights are indicated by a Creative Commons license in the record and/ or on the work itself. This Thesis has been accepted for inclusion in WVU Graduate Theses, Dissertations, and Problem Reports collection by an authorized administrator of The Research Repository @ WVU. For more information, please contact researchrepository@mail.wvu.edu. 
Masthead Logo

Graduate Theses, Dissertations, and Problem Reports

2019

A Timeless Ritual

Luke Thomas Doyle

Follow this and additional works at: https://researchrepository.wvu.edu/etd

Part of the Ceramic Arts Commons 


\title{
A Timeless Ritual
}

\author{
Luke Doyle \\ Thesis submitted to the College of Creative Arts \\ In partial fulfillment of the requirements \\ for the degree of \\ Master in Fine Arts in Ceramics
}

Shoji Satake, M.F.A, Chair

Robert Moore, M.F.A

Jason Lee, M.F.A

Naijun Zhang, M.F.A

School of Art and Design

Morgantown, West Virginia

2019

Ceramics, Industrial, Steel, Pottery, Soda Firing, Glaze

Chemistry, Process, Forging, clay, mold-making

copyright 2019 Luke Doyle 


\section{Abstract \\ A Timeless Ritual \\ Luke Doyle}

This written thesis is the supporting documentation for A Timeless Ritual, my Master of Fine Arts thesis exhibition. The exhibition seeks to define my expression of aesthetics through utilitarian vessels to create a sense of nostalgia with the user my mimicking industrial objects.

The research pertaining to my thesis explores the interactions between object and user. A patina layered over time evokes a sense of age, weathered memories of a time once lived. I look for these subtle nuances in form. Borrowing an aesthetic from manufactured products and reviving it in a domestic space is where my pots takes life. My references to industrial steel mills, production assembly lines and the shell of the city of Pittsburgh that was once celebrated as such, implements a narrative and attachment with the user. Creating utilitarian vessels replicating this aesthetic builds a relationship between the piece and the user. Activating the living environment by giving the user a gateway for conversation, provokes a remanence of a different time, and rejuvenate memories triggered by these nostalgic elements of my pottery. 


\section{Acknowledgements}

Through my time researching and creating my thesis. There were those constantly willing to help and push me through and help me till the last minute. I would like to thank those individuals for their constant support, efforts, and time spared to provide guidance and structure in my education. A very special thanks to Robert "Boomer" Moore, Shoji Satake, Alison Helm, Dylan Collins, Jason Lee, Brandon Schnur, Larry Whittington, Cornelius Hugo, and Tyler Stonestreet, for always being there for advice and guidance. 
Table of Contents

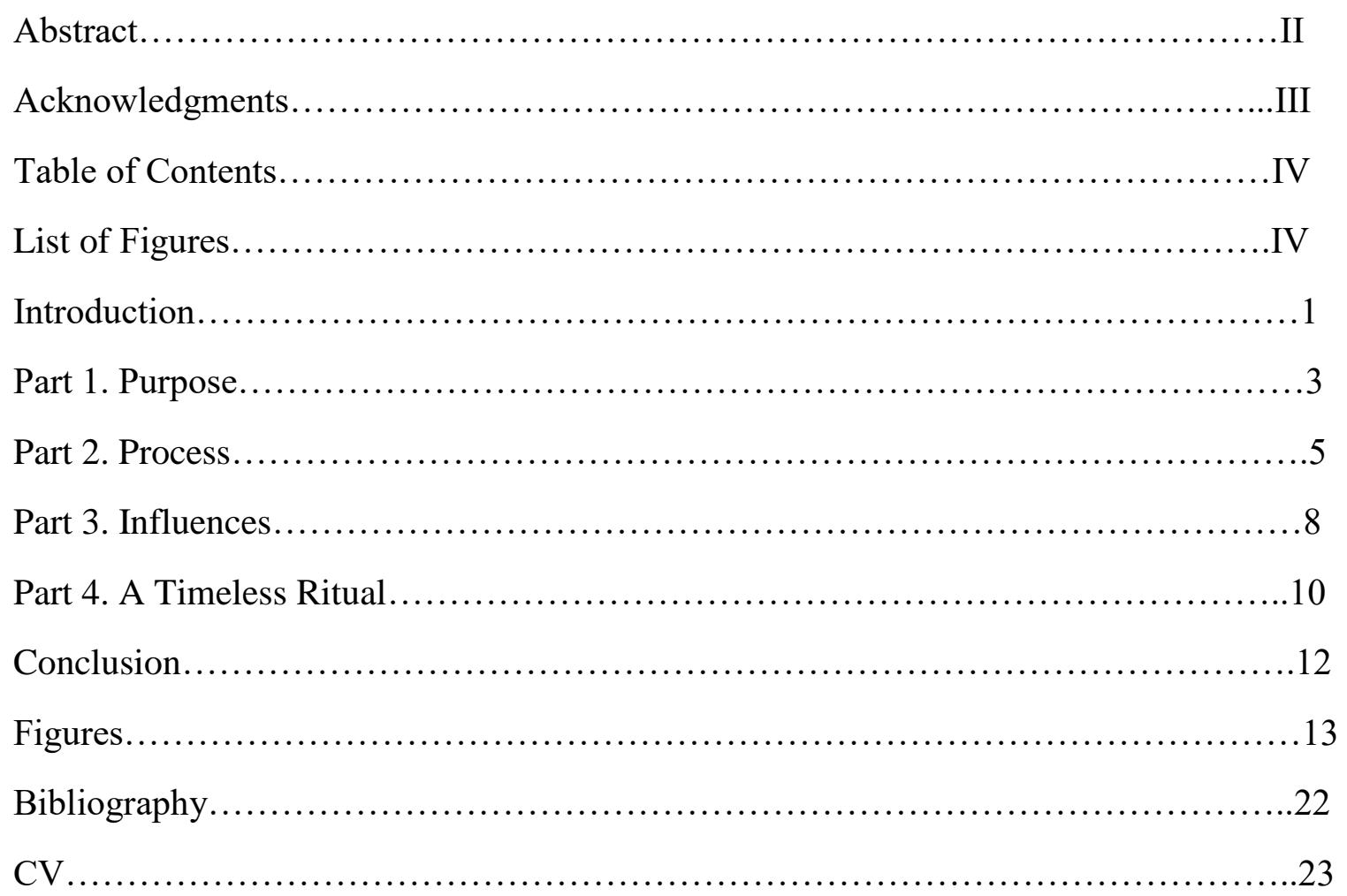


List of Figures

Figure 1. Luke Doyle . "Coffee Pour Over" 2019......................................... 13

Figure 2. Luke Doyle "Lidded Pitcher" 2019....................................... 14

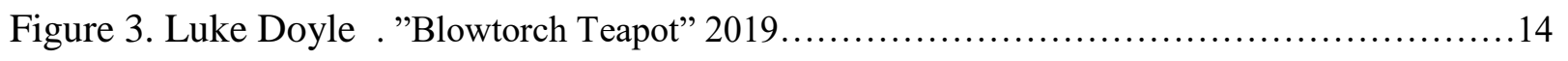

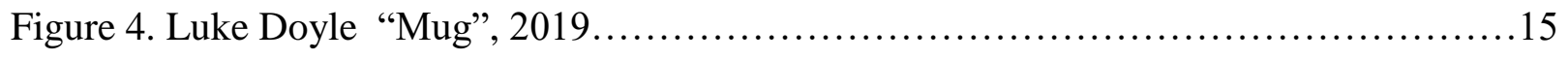

Figure 5. Luke Doyle "Sewer Platter", 2019....................................15

Figure 6. Luke Doyle . "Acid Ball Vase", 2019................................... 16

Figure 7. Luke Doyle . Rusted Bolt Photo by Luke Doyle..............................16

Figure 8. Luke Doyle . "Acid Ball Vase", 2019..................................17

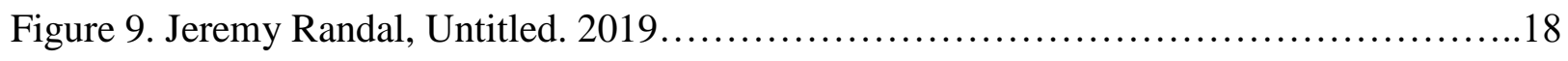

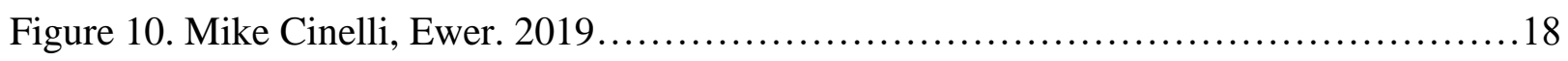

Figure 11. Ted Neal. Silo 2, 2019............................................... 19

Figure 12. Bernd and Hilla Becher. "Gas Tanks", 1983 ................................19

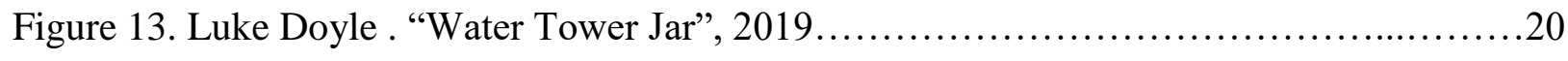

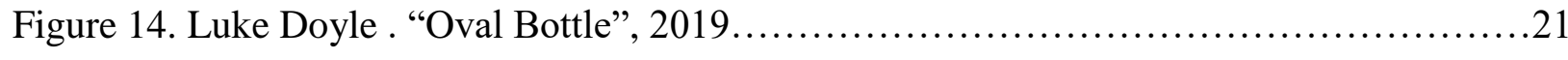

Figure 15. Luke Doyle "Water Tower Jar" 2019.......................................21 


\section{$\underline{\text { Introduction }}$}

I grew up in a city that was once celebrated as a mass manufactured steel producing industry, the city of Pittsburgh. Although I was born in 1988, I was still able to have the chance to observe and witness the shells of the city that once was covered in soot produced by the steel mills that encompassed the landscape. Having the opportunity to work in factories that casted glass from steel molds, mixed clay, and produced pottery, imbedded a sense of production in the way I live my daily life. I became very habitual in the way I think, act, and make art.

My pottery revolves around my background making mass produced objects, yet my work is meticulously crafted using this muscle memory imbedded through repetition. Pottery speaks community, engagement, and utility. Pottery provides a way to live and experience art in some of the most intimate areas of life. It touches your mouth; your fingers rub against the textures while you use pots and promotes conversation and utility. In my work I strive to create a habitual process unlike typical "Pots" imply. Forging steel stands my pots rest upon creates a place for my pots to return to, this creates a ritual in the work. They also rely on that stand, pots intentionally crafted with round feet to always have a resting place. Taking advantage of my background working in factories, created a ritual in how the work is made in my studio.

We commonly take advantage of the way manufactured objects guide us in the world we live in today. People sometimes don't recognize tactile paving placed on our walkways, or the rivets on a bridge, textures on handrails that communicate to use when to stop or go. I'm inspired by these subtle cues mass produced objects and textures influence our everyday lives and replicate them in my work. Using methods such as slip casting, hand pressing clay, throwing, and metal forging, I attempt to create a sense of nostalgia and remanence of the industrial age we currently live in. 
Creating a set of work to be used in combination such as a coffee pour over (Fig 1), or a set of mugs crafted to sit on a specific stand, promotes the user toward the specific function its intended for. Casting drawer handles, bolts, nuts, and screws imply the connections, mass production, and simple textures my work conveys. Formulating specific glazes that resemble aged steel, worn paint, and raw surface, enhances the nostalgia my pots reference.

Associating found objects for my pots can be commonly found in any factory, but also imitate man made objects that do not exist anymore, such as large acid ball chambers, storage vats, and typical objects you would find in antique shops. Using these object's as influence guide the way I produced my work and the molds made to create these specific objects.

This paper will document the aesthetics and formal decisions I make in order to create my work, and the meticulous process I use to make pots. 


\section{$\underline{\text { Purpose }}$}

The purpose of my work is to create a sense of nostalgia and a habitual process in how the work is used. Creating stands where a vase rests upon separates its value from a generic ware you may find in a store. Rounded feet under a coffee pot force the user to return it where it was intended to (Fig 2). When work is created to serve a specific purpose, the user subconsciously obeys that intended use. This is very similar to how we live our daily lives. We obey street lights, or use a specific key to start automobiles, I strive to make pottery that one might not use on a daily basis, but rather during a moment where they can take the time to enjoy the object for what it is, whether it directly represents an object (such as an industrial blow torch (fig 3) ), or a texture to be felt on a mug or cup ( rivets, fan texture, bolts)(fig. 4).

We typically let our pottery rest inside cupboards or shelves and retrieve them as needed. This creates a subconscious ritual before and after the dish is used. When a stand is created for a specific set or piece, it is projected differently. It's given a hierarchy over something that

otherwise rests on any other surface. Its that sense of importance and presentation that completes my work. Once a piece has served its function, it goes back to display on its intended resting place (its stand).

It its rawest essence, my pottery focuses on a functional object, and references utility. Bernard leach states "Potting is one of the few activities today in which a person can use his natural faculties of head, heart, and hand in balance. If the potter is making utensils for usesimple bowls, pitchers, mugs, and plates- he is doing two things at the same time: he is making ware that may give pleasure in use, which provides one form of satisfaction to the maker, and he is traveling in the never-ending search for perfection in form, which gives a different 
gratification. ${ }^{1 "}$ In the 21-st century, the "pot" has now been apart of daily life for tens of thousands of years, from Ming Dynasty blue and white ware, to a plain white diner mug. I constantly keep this in mind when finding my place in ceramic history. A diner mug is meant to be used constantly, braised along table surfaces and handled in a rough manner. It is mass produced and crafted purposefully to be thick and heavy to withstand such use every day. Although I constantly reference mass production in my work, it is not mass-produced. I create a sense of irony using plaster molds of already mass-produced objects to make a unique piece, which makes the user second guess the textures and begin to pay attention to the subtle references I've made with the attachments on my work.

As a postmodern ceramic artist, I am taking elements from our industrial history (past and present) and using them to make utilitarian ceramic vessels promoting function within the household. My pottery invokes a sense of nostalgia using textures and layers from our everyday life sparking conversation and a habitual process in a domestic space.

\footnotetext{
${ }^{1}$ Bernard Leach “ The potters Challenge” New York: Dutton. 1975
} 


\section{$\underline{\text { Process }}$}

The underlying element in my work is the production aspect and is the major component that creates my fascination with the work I make. Aside from formal decisions and my obsession with the aesthetics of industrial/manufactured objects, the ritual in which I make work is just as important to me than the finished product. When I find an element in our environment I wish to incorporate into my work, a formal process is mapped out and then the proper steps are taken to turn that idea into a finished product. This is very similar to how I was trained to work in factories and production business.

The attachments, textures, and other elements in my work are primarily made from objects casted in plaster molds. When I make a mug, precision and hiding any evidence of the hand is very important. We commonly go about our day opening doors and cabinets using handles manufactured for specific use. I treat my work similarly by using found objects, making plaster molds and casting them out of clay, then attaching them to the piece. These handles are commonly found in our daily lives and placing them on a utilitarian object gives that sense of nostalgia that I am looking for in my work. Taking pride in the construction of the mold; clean edges, minimal flashing, and proper mixing ratios between the water and plaster, are parts of the process that I obsess over. When I use these textures in the work, for example blister tactile paving used for the blind at the end of a sidewalk, I will interact with that environment by casting that object in public and leaving no trace behind. In doing this I'm able to leave my studio and observe the environment and how people interact with it. Others are then able to relate to the texture when using my work. I use molds taken from fire hydrants, man hole covers 
(fig 5), expanded metal, tactile pavement, water spigots, and anything I can use to create more than just a typical experience with a piece of handmade pottery.

Most of the structures and forms I am influenced by tend to be round objects, which is why make wheel thrown vessels. There are larger vase and lidded jars inspired by photographers Bernd and Hilla Becher, they are industrial structures that once were functioning objects and no longer have any use or are decomposing from lack of. Incorporating steel support structures for these vessels creates a direct relationship with metal and ceramic. I use a forging method of bending round stock steel, and plasma cutting sheet metal. When throwing, I create a gallery on my forms, so a precisely forged/cut ring can fit around the base of them. Placing my pottery on a stand mimics a sense of scale and distinguishes it (Fig 6). Forging, cutting, welding, and painting adds another segment to my process which enables me to make multimedia art.

Mimicking a surface exposed to the elements over an extended period such as weathered steel, erosion of pavement, and rust, are surfaces I explore (Fig. 7). I use techniques in glazing, sandblasting, and atmospheric soda and wood firing to bring out these effects. Walter Benjamin states "Even the most perfect reproduction of a work of art is lacking in one element: its presence in time and space, its unique existence at the place where it happens to be. This unique existence of the work of art determined the history to which it was subject throughout the time of its existence. This includes the changes which it may have suffered in physical condition over the years as well as the various changes in its ownership." "My work does not directly copy a specific object, that would be considered trompe l'oeil, my pots take fractures of elements from different objects (not pottery) to make ceramic pots.

\footnotetext{
${ }^{2}$ Walter Benjamin, "The Work Of Art in the Age of Mechanical Reproduction," 2010
} 
The glazes I use are altered when Soda Ash (sodium carbonate) is diluted with hot water and sprayed into the kiln at high temperatures to flux the glaze. This promotes crystal growth and pulls the glaze down the work creating a weathered aesthetic(Fig. 8). I spend time in a chem lab formulating these glazes to promote these specific surfaces I'm replicating. Once satisfied with the glaze, some of the vessels are made with colored clay blended with encapsulated mason stains to change the color and depth of the glaze entirely. Doing this allows me to use one formulated glaze over the same clay body with just $6 \%$ of stain added to the clay, this is easy math and an effective way to create different hues of the same glaze.

When loading a kiln, the result of the firing is partially unknown, despite the amount of testing and familiarity with the kiln. This is a way of letting go of the work and allowing the elements introduced into the kiln alter the glaze or raw clay body. This act of exposure to the unknown mimics the way our environment and elements effect our steel bridges, water towers, and other structures in our environment.

Once the work has been unloaded and analyzed, specific pieces are chosen to be sandblasted to create more variation in the surface. This typically promotes a Matte surface resembling decomposition and breakdown of materials. The steel stands are also sandblasted to achieve the same effect. 


\section{$\underline{\text { Influences }}$}

I draw inspiration from ceramic artists whose work represents precision, industrial aesthetics, and who are process oriented. These ceramic artists include Jeremy Randall, Ted Neal, and Mike Cinelli. I take inspiration from each of them in different variations. I also am inspired by the structures photographed by Bernd and Hilla Becher, and their philosophy behind their images.

Jeremy references rural American architecture and antique implements that tie the viewer back to the domestic space, allowing for quiet contemplation and a reminder of a simpler time. He is using these soft pastel-like colors to celebrate iconic objects such as an old rusted tractors, and other weathering industrial objects (Fig 9). Through Jeremys work I am strongly influenced by his use of texture. A dark clay body seeps through his terra sigillatta surface in combination with a black iron wash overlapping, creating a sense of age and prolonged use. His work also breaks space in combination with color and texture work to make a strong composition and coherent body of work. I'm also drawn to his usage of multimedia materials using nichrome wire to support different parts or add to his trompe l'oiel aesthetic.

Mike Cinelli is interested in science fiction, so in his work he seeks the relics of a future that has yet to occur. Pursuing objects that are familiar and identifiable, he's layering the aesthetics of both history and science fiction and leaving a gap for the user to create their own narrative as well. Aside from the humor and character mikes work portrays, I'm drawn to the crisp line work and attention to detail mike can put into something as common as a mug (Fig 10). Time is not a factor in his work and casting different parts to add to his forms give it this industrial look. I'm naturally drawn to this surface and the glaze texture, but also using materials to keep the vessel functional. 
Ted Neal plays with the idea of making utilitarian vessels with the purpose of personal consumption based on the forms of global consumption. He expresses his concern for our overuse of natural resources. Ted makes stands for his work, which I take a huge influence from. His integration of metal and relationship with his pottery are among similar goals in my own work (Fig. 11). His reduction cooled pots give off a smoky black aesthetic, and I have been pushed to stain my clay body in different hues in my discovery for that weathered industrial aesthetic.

Bernd and Hilla Bechers were photographers based out of Western Europe. They photographed monumental industrial structures with a lifespan. Most of the structures the photographed (water towers, acid balls, gas tanks, silo's) are no longer standing today. Their compositions had a combined aesthetic of form and function, centering the subject directly in the middle of each print. The Bechers work influences most forms that are constructed in my studio. I am draw to the verticality and cylindrical aspects of the structures they photograph, and also the texture's the structures wear (Fig 12). 


\section{$\underline{\text { A Timeless Ritual }}$}

A timeless ritual is a thesis show based on the history of ceramics and the ritual involved in its daily use. This body of work abstracts the idea what a typical "pot" implies by the construction of a utilitarian vessel based off the many industrial objects we view and use during out daily lives. Using those mass-produced objects from the molds I create a sense of irony connecting them to a one of a kind vessels. I reference blast furnaces, water towers (Fig. 13), and the many textures we use and witness during out daily routines.

The ritual pottery has induced in the last 20,000 years meets us at our dinner tables, provides space for plants to grow, and simply incorporate a visual aesthetic in our domestic space. As a $21^{\text {st }}$ century artist I abstract that idea by pushing the limit of a utilitarian object by directly referencing the industrial objects we interact with and creating a ritual with those vessels by constructing stands in which they rest and cannot live without. Building stands made from steel and ceramic create a resting place for these utilitarian vessels by constructing them with rounded feet. This creates a bond with the vessel and stand, and a ritual with the user. Once the work has completed its function it must then be returned to its stand. This makes the stand just as important as the vessel that sits upon it, but also makes it a unique object that may be only used during special occasions, or simply for aesthetics. The overall relationship between these vessels is that they contain. Whether it's a whiskey bottle (Fig. 14), a pitcher, a lidded bowl, or a water tower jar, everything revolves around the idea of the pot, and pots contain.

Using a variety of techniques, firing methods, and construction, process is the driving element in this body of work. The majority of the work is fired in a soda kiln to Cone 11, in a 
reduced atmosphere. This atmospheric firing creates spontaneous effects in the glazes applied to the vessels. The water tower jars are fired in a non-atmospheric kiln to promote brighter tones to represent pattern structures I've witnessed during my travels and life experience.

Placing these utilitarian vessels on steel stands represent the structures they are influenced by. Up to this point I have never actually created works from steel, but always operated objects created from steel, this created my fascination and problem-solving process to incorporate them into the utilitarian vessels in my show. Because I make the vessels with rounded feet its important the steel is forged correctly to fit the piece (Fig. 15.).

The rounded bottoms are elements that every object in the gallery shares and relying on a stand. Other influences are the industrial references (surface, texture, form), and that the objects all contain. Its those four elements that bring the body of work together to make it coherent and relatable.

When a person walks into the gallery, the purpose is to incorporate a sense of nostalgia, the long road trips with families etc.... The lonely walk to work everyday but looking up to a monumental structure to take their thoughts away for just a second. To spark a memory, or experience one once had, even if its just for a moment, to ease someone and remind them to slow down for a glass of whiskey, present a dish, or to let a moment resonate within them for a minute. The work portrays my inspirations but also allows that spark of memory for someone else. 


\section{$\underline{\text { Conclusion }}$}

During my 3 years in the West Virginia Ceramics department, I have had the opportunity to grow not only as an artist but also as an instructor, and human being. I've been given opportunities to travel and plant the seed for a body of work that will continue to grow as I further my career in ceramics. Using my background in factory work and fascination with industrial structures and objects, I was able to learn various skills and techniques to successfully make a coherent body of work. My thesis show will continue to resonate within me and grow into something bigger and better. The result of my thesis exhibition has only solidified and spark new concepts to further my path as a ceramic artist. 


\section{$\underline{\text { Figures }}$}

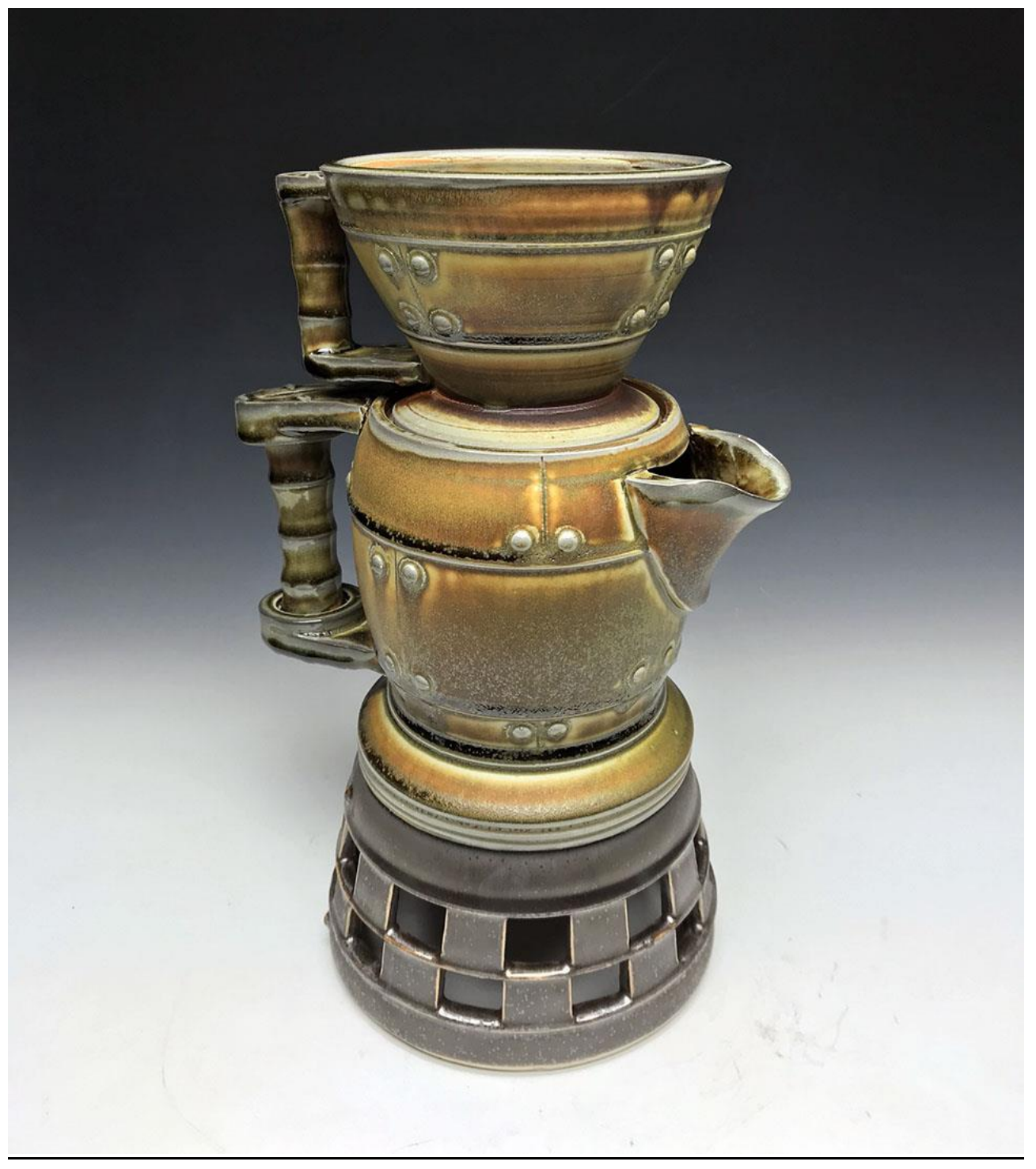

Fig. 1. "Coffee Pour Over" 15 x 8 x 10. Ceramic, Cone 11 Reduction, Soda Fired 


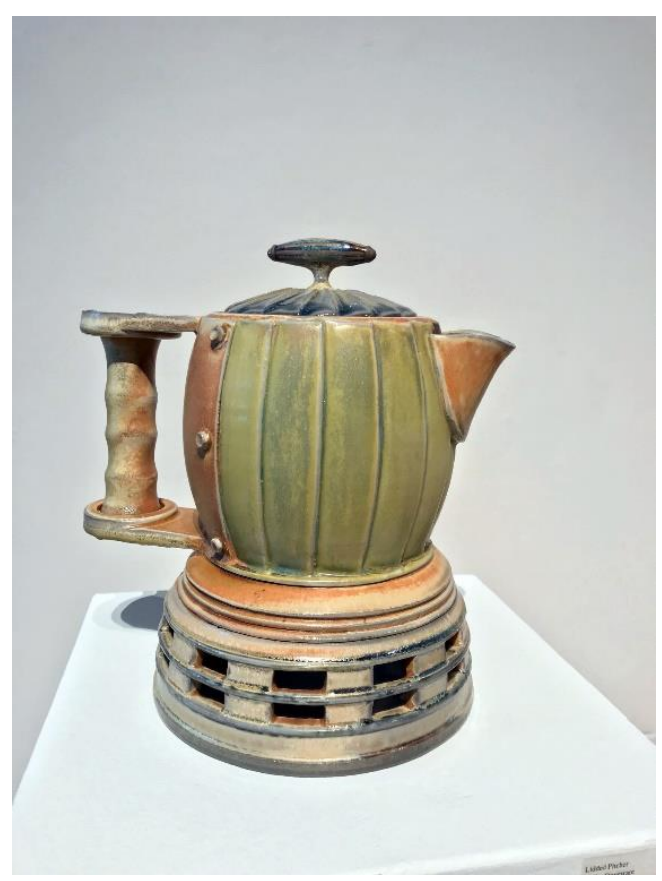

Fig. 2. "Lidded Pitcher" 13 x 6 x 9. Ceramic, Cone 11 Reduction, Soda Fired

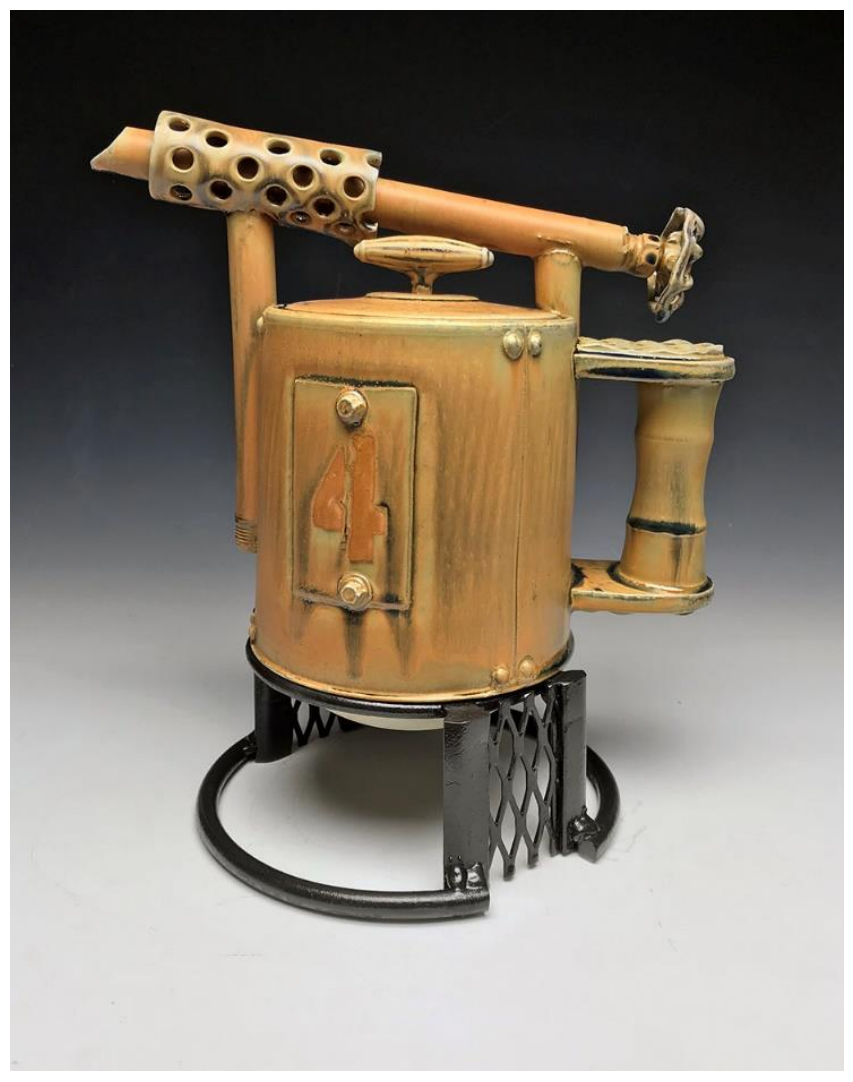

Fig. 3. "Blowtorch Teapot" $14 \times 10$ x 12. Ceramic, Steel. Cone 11 Reduction, Soda fired 


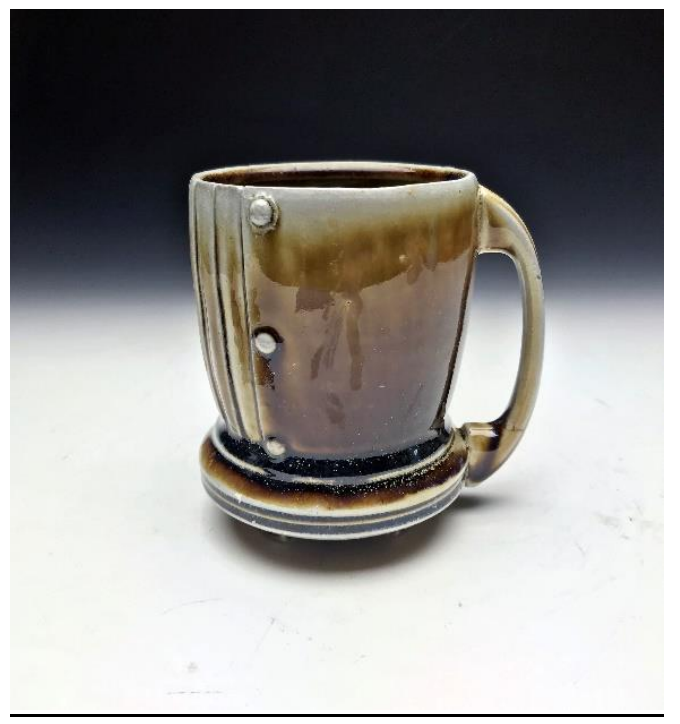

Fig 4. "Mug" Ceramic. 5.5 x 4 x 3.5 Cone 11 Reduction. Soda Fired

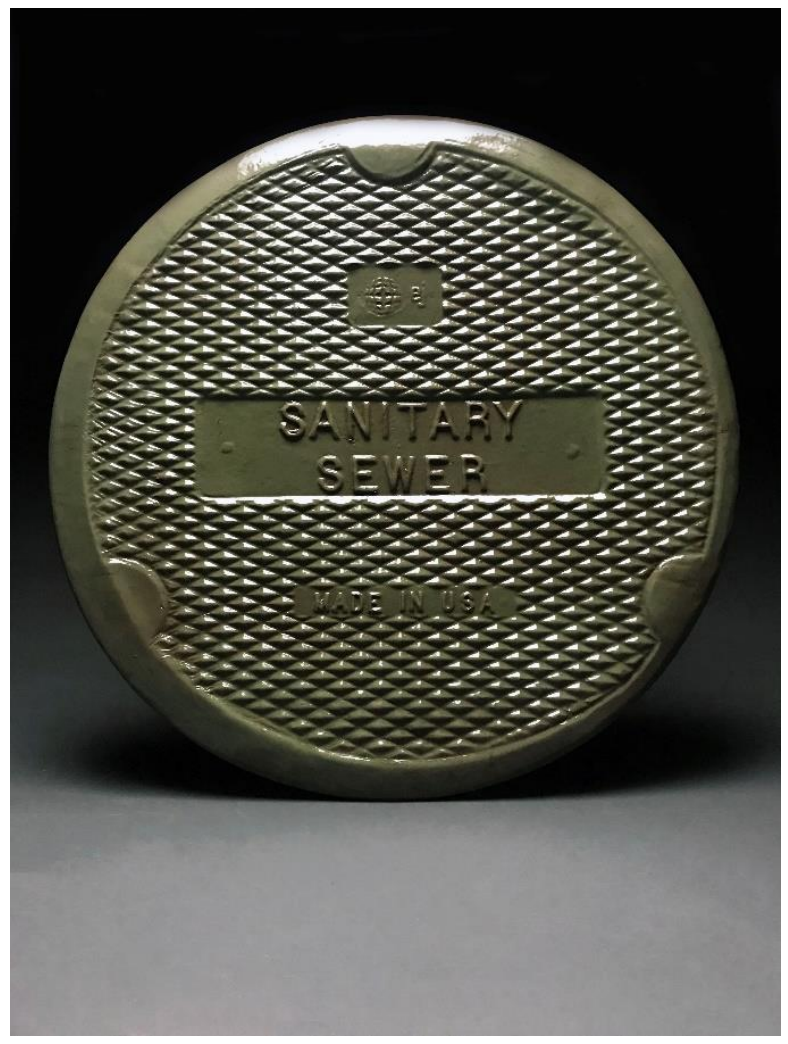

Fig. 5. "Sewer Platter" 5 x 23 x 23. Ceramic, Cone 5 Oxidation 


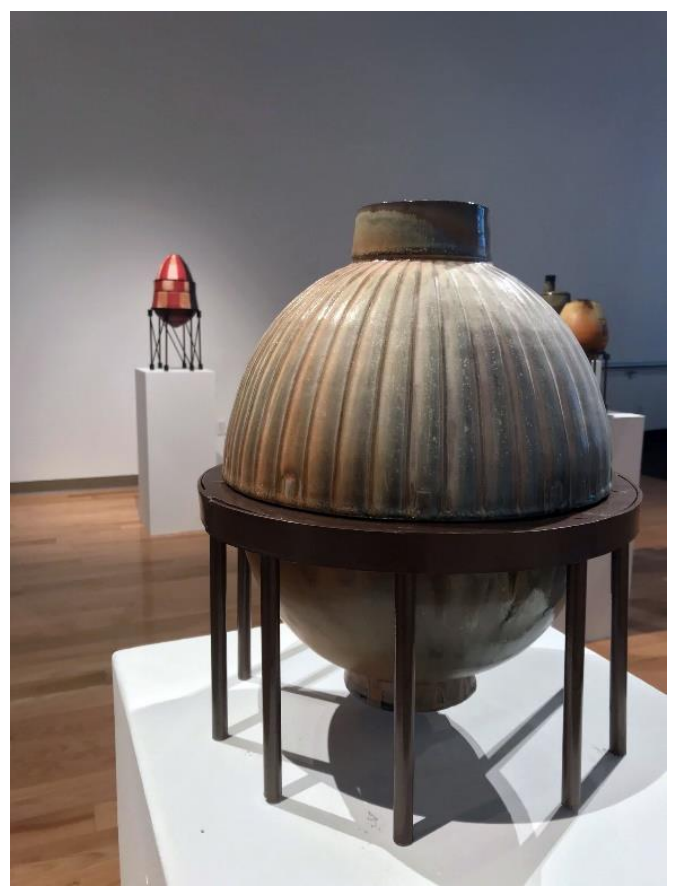

Fig. 6. "Acid Ball Vase" 2 ft 16 x 16 Ceramic, Steel. Cone 11 Reduction, Soda Fired

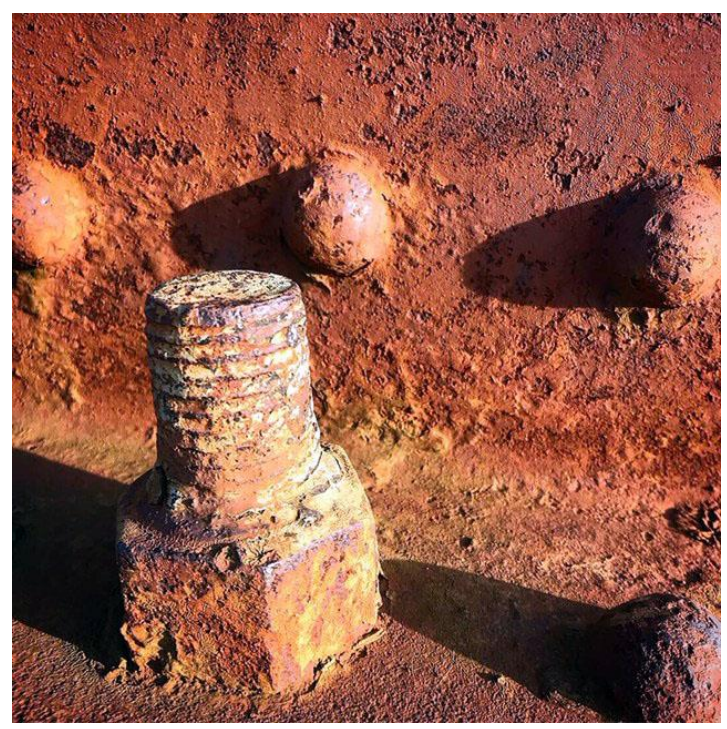

Fig. 7. Rusted Bolt. Photo taken by Luke Doyle 


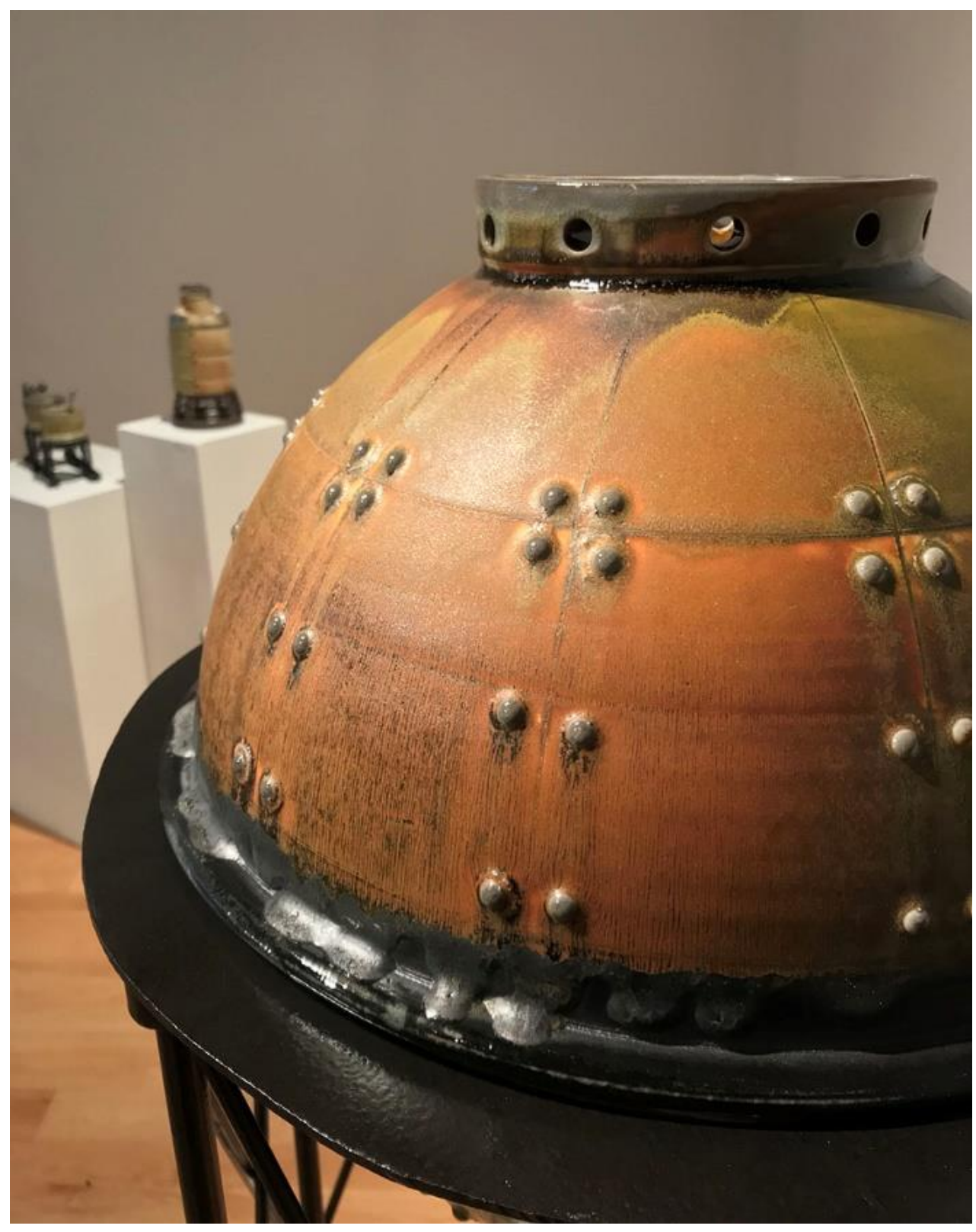

Fig. 8. “Acid Ball Vase” Detail. Ceramic, Steel. Cone 11 Reduction, Soda Fired. 


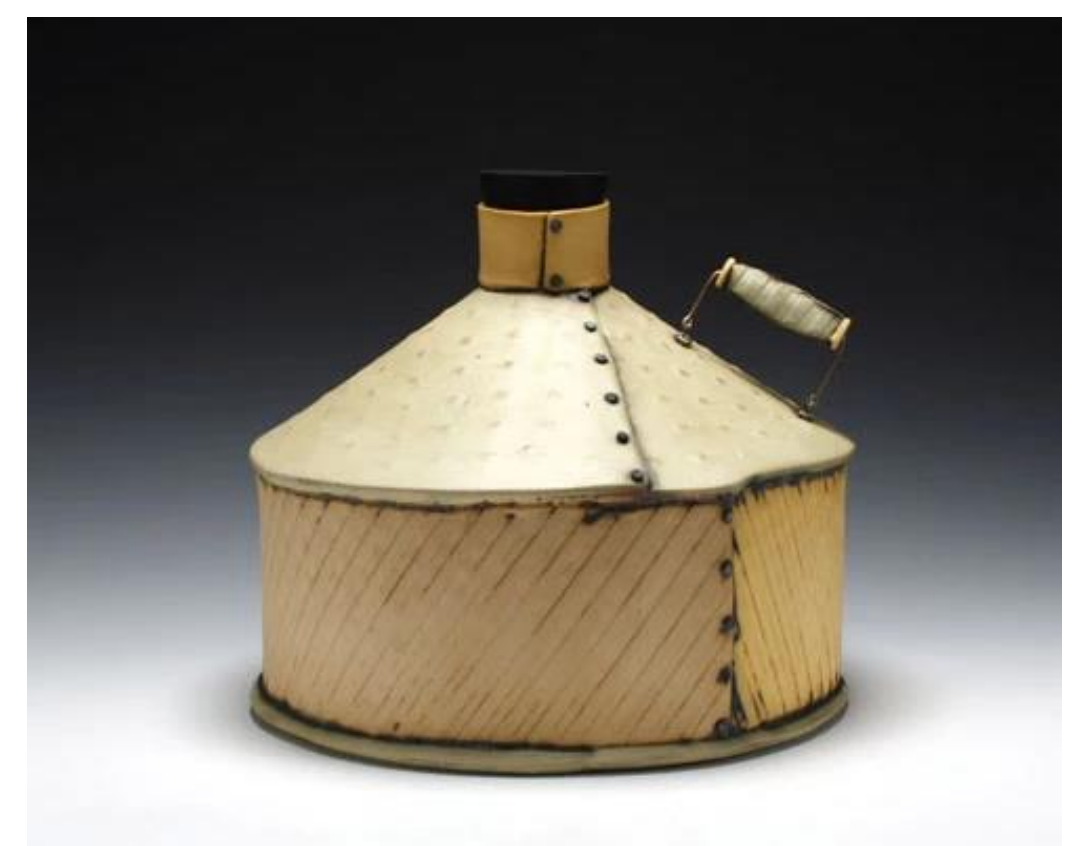

Fig. 9. Jeremy Randal, Untitled. 2019. Earthenware, Low Fire.

https://www.jeremyrandallceramics.com/images (Date accessed 04/10/2019)

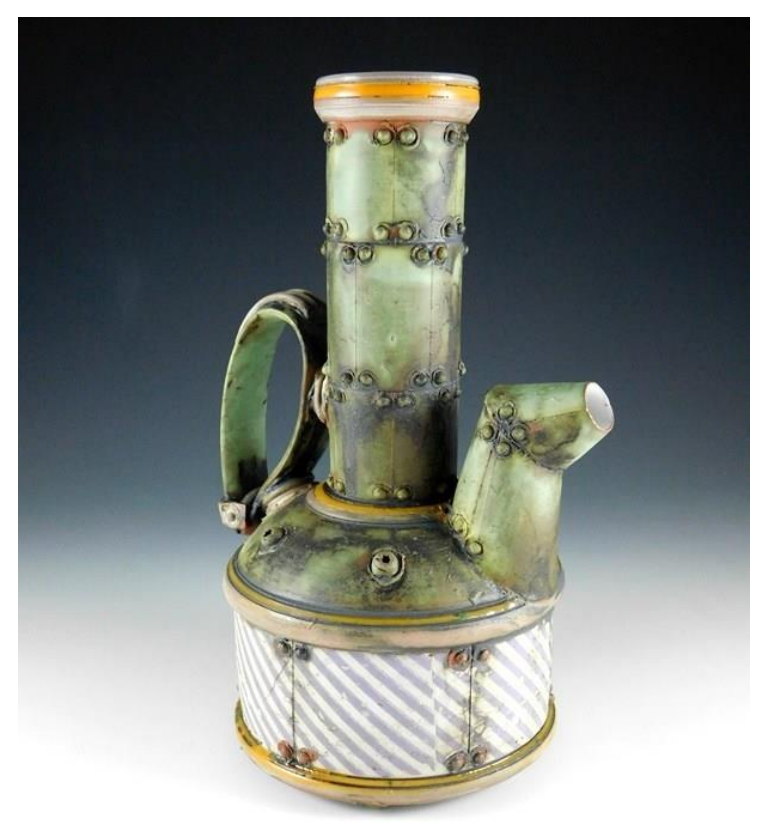

Fig. 10. Mike Cinelli, Ewer. 2019, Earthenware, Cone 04 Oxidation.

https://companiongallery.com/product/ewer-mc275/ (Date accessed 01/10/2019) 


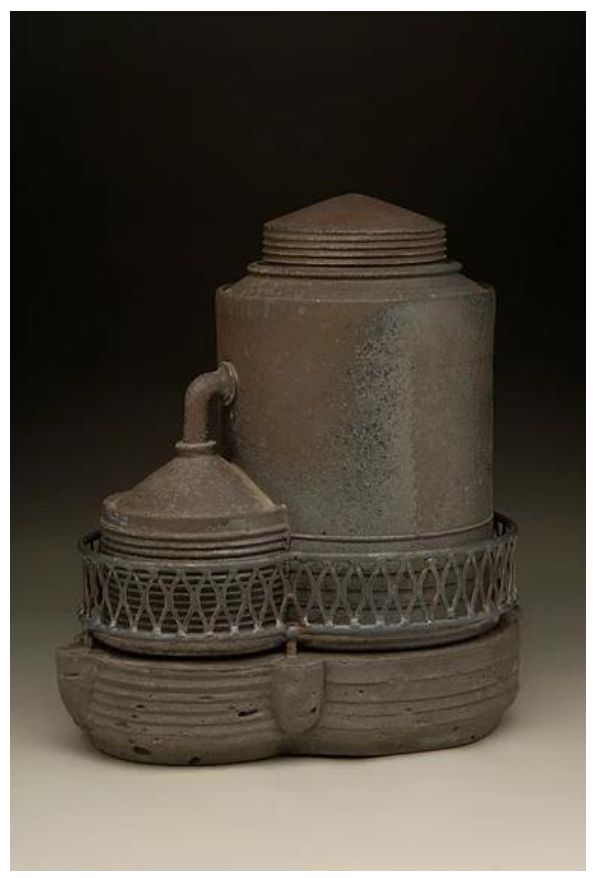

Fig 11. Ted Neal. Silo 2, 2019. Ceramic, Cone 12 Reduction Cooled, Wood-Fired https://www.tednealceramics.com/work (Date accessed 04/10/2019)
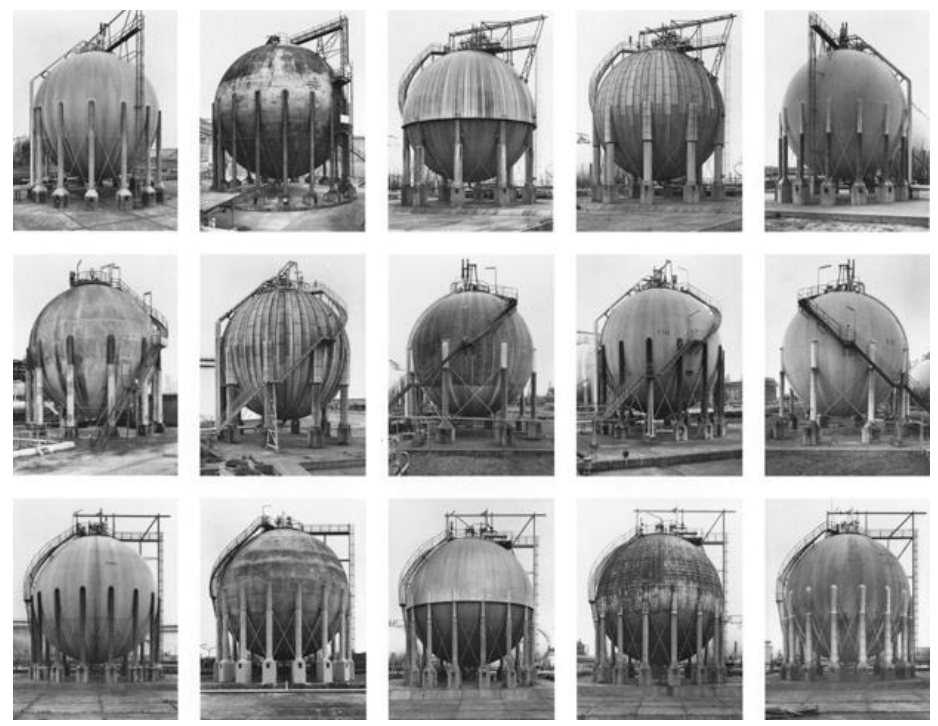

Fig 12. Bernd and Hilla Becher. "Gas Tanks", 1983. Photograph

https://www.phaidon.com/agenda/photography/articles/2012/november/21/hilla-becher-interviewed-atparis-photo/ (Date accessed 04/10/2019) 


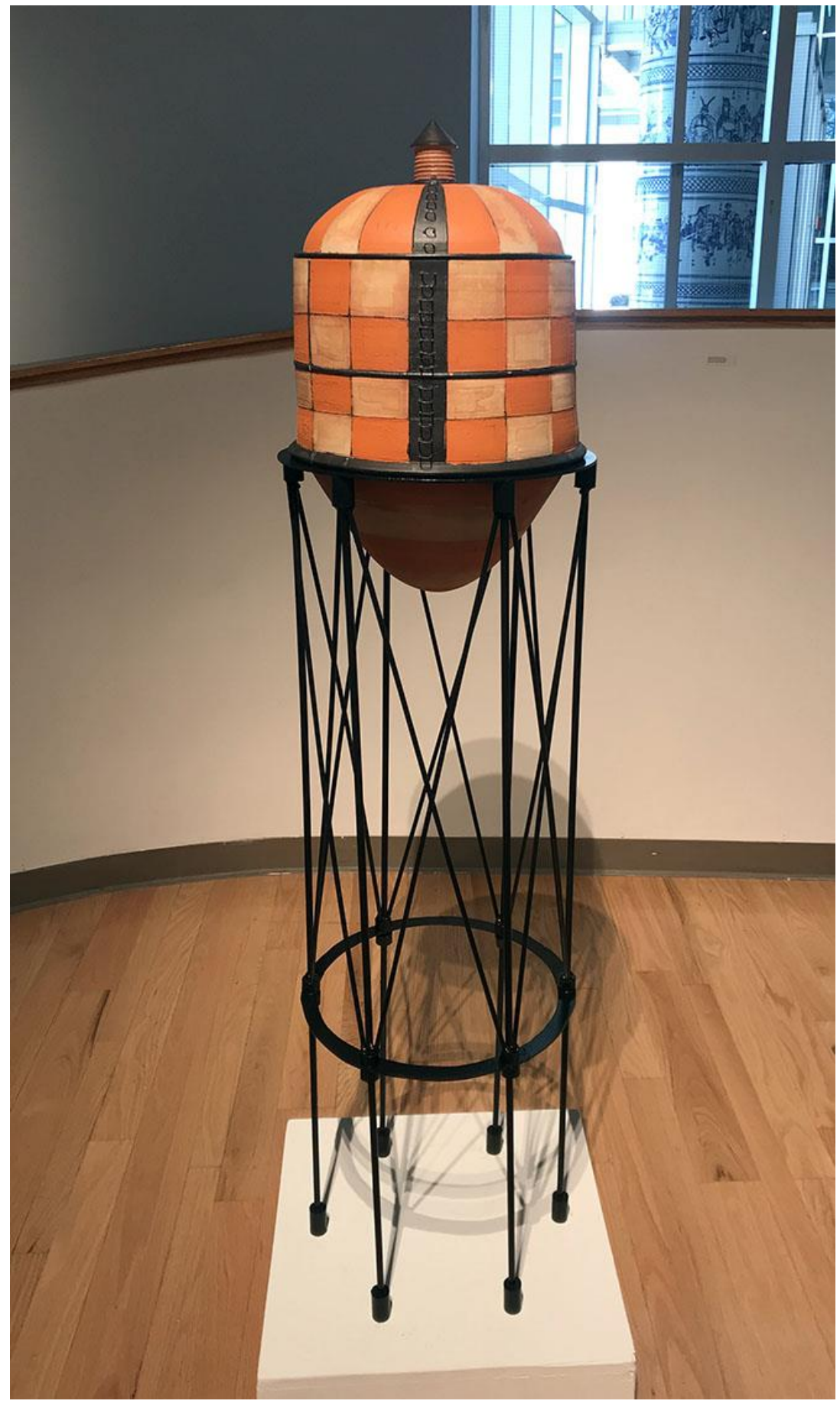

Fig. 13. "Water Tower Jar" $5 \frac{1}{2} \mathrm{ft}$ x 17 x 17. Ceramic, Steel, Kanthal Cone 10 Reduction 


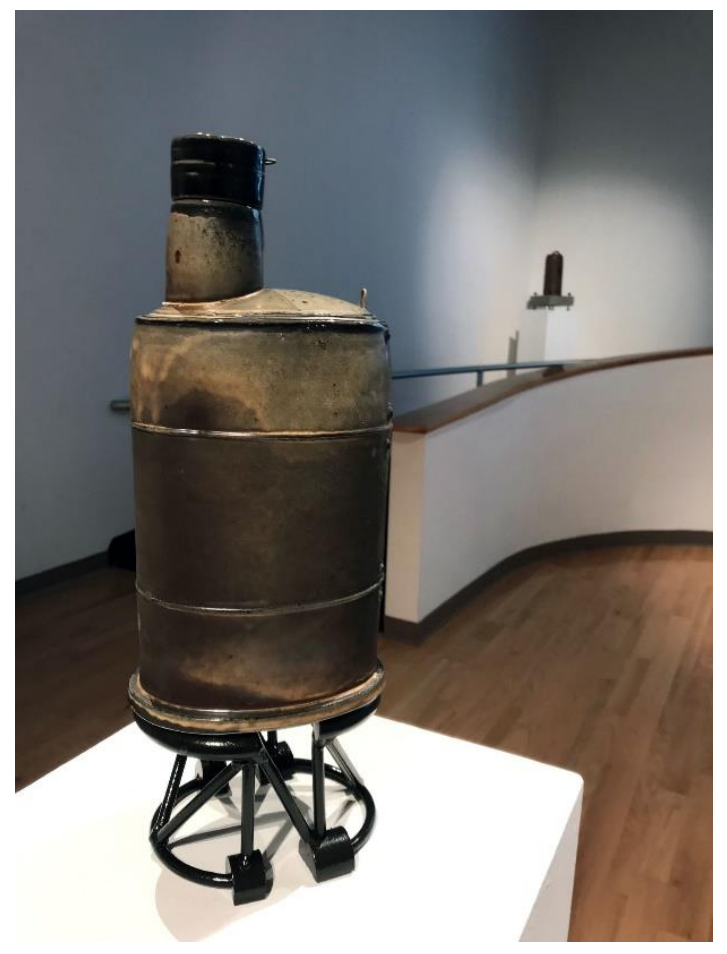

Fig. 14. "Oval Bottle" 14 x 7 x 3.5. Ceramic, Steel, Kanthal. Cone 11 Reduction, Soda Fired

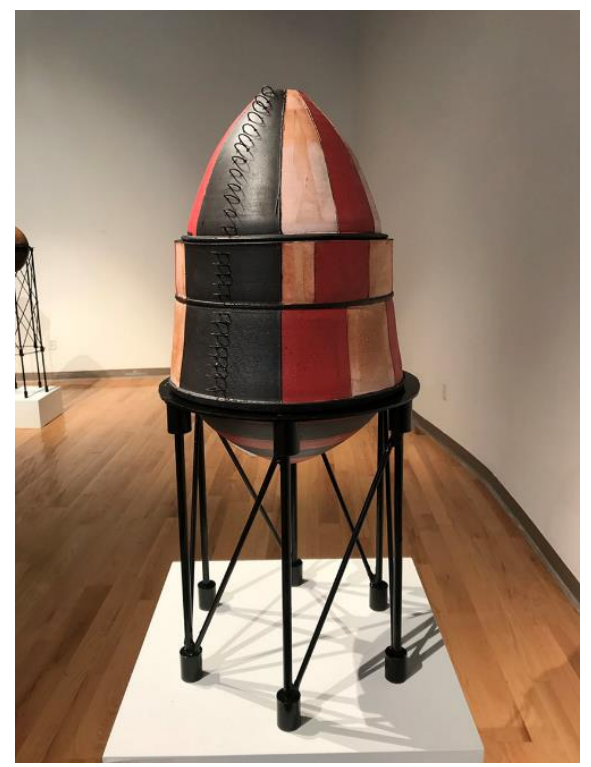

Fig. 15. "Water Tower Jar" $2 \frac{1}{2} 2 \mathrm{ft}$ x 15 x 15. Ceramic, Steel, Kanthal. Cone 10 Reduction 


\section{Bibliography}

Benjamin, Walter. "The Work Of Art in the Age of Mechanical Reproduction." 2010.

"Bernd and Hilla Becher." Claudio Bravo Biography - ClaudioBravo on Artnet. Accessed November 26, 2018. http://www.artnet.com/artists/bernd-and-hilla-becher/.

Leach, Bernard. The potters challenge. New York: Dutton, 1975

Rawson, Philip S. Ceramics. Philadelphia: U of Pennsylvania, 1984. Print.

Yanagi, Sōetsu, and Bernard Leach. The unknown craftsman: a Japanese insight into beauty. New York: Kodansha USA, 2013. 


\author{
Luke T. Doyle \\ Doyleceramics@hotmail.com
}

412-443-9006

\title{
Education
}

2017-present West Virginia University,WV MFA Candidate

2017 WVU China study abroad program, Jingdezhen

The Pottery Workshop

2013 Edinboro University of Pennsylvania, PA BFA in Ceramics

2007-2010 Community College of Allegheny County, PA Fine Arts

\section{Teaching Experience}

2017-2019 West Virginia University, West Virginia

GA Instructor; Foundations/Ceramics

2017 Visual Arts at Chautauqua Institution, New York.

Summer instructor.

2017 Visiting Artist Lecture Series, Jingdezhen, China.

Lecture/Slide Presentation.

2014 Penn Hills High School, Pittsburgh, Pennsylvania

2 Day Workshop; Wheel Throwing Demonstration, Hand Building Demonstration

2014 Pittsburgh Center for the Arts, Pittsburgh, Pennsylvania

Class Instructor; Wheel Throwing, Hand Building, Raku Demonstration Lecture

2012 Edinboro University of Pennsylvania, PA

Raku Firing Workshop ; Provided techniques and firing methods during a Raku Firing and a wheel throwing demonstration

2010 KDKA, "the Today Show", Pittsburgh, Pennsylvania

Wheel Throwing Demonstration

2010

Brick Pitt Studio, Pittsburgh, Pennsylvania

Clay instructor

Exhibitions 
"Crossing Paths" NCECA Exhibition Curated by Kyle Houser; Pittsburgh Center for the Arts

2018

2018

2017

2016

2015

2015

2015

2014

2014

2014

2014

2013

2012

2012

2011

2011

2011

"CCAC Student Show" NCECA Exhibition Curated by Joseph Delphia; Community College of Alleghenny County Ton Pottery

“Last Call II” Juried by Jennifer Allen, Companion Gallery

“72 Steps” Mufei Gallery

“Edinboro Clay Club Show" Clay Place at Standard

“Cup, The Intimate Object” Charlie Cummings Gallery

“Keystone Collegiate Exhibition” Juried by Bill Strickland

“Nu Contemporary" Ceramics Invitational

“Glaze by Fire” Atmospheric Invitational, Taos Clay

“DRINK!' Cup Show, juried by Doug Peltzman, Slipe Gallery

"Energy of the Future" NCECA Student show, Juried by Kristen Kieffer and Bruce Cochrane

"Clarion Mug Show" Regional Juried Show

"October Evenings" Show, Regional Juried Show

“Edinboro Student Show" Juried Show

"6-10-soda" Group Exhibition, Bates Gallery

“Clarion Mug Show" Regional Juried Show
"Industry and Imagery" NCECA Exhibition Curated by Dan Kuhn;

Slippery Rock University, Pennsylvania

“Daily Ritual” Cup Show, Juried by Ron Korczynski, Co-Op Gallery
Pittsburgh, Pennsylvania

Pittsburgh, Pennsylvania

Pittsburgh, Pennsylvania

Humboldt, Tennessee

Jingdezhen, China

Carnegie, Pennsylvania

Gainesville, Florida

Brockway, Pennsylvania

Saxonburg, Pennsylvania

El Prado, New Mexico

Hartford, Connecticut

Houston, Texas

Clarion, Pennsylvania

Meadville, Pennsylvania

Edinboro, Pennsylvania

Edinboro, Pennsylvania

Clarion Pennsylvania

Solo Exhibitions

2019
“A Timeless Ritual” Laura Mesaros Gallery; West Virginia University

“Surface Techniques” Bill Campbell's Stonewall Gallery

“Altered Forms" Bates Gallery, EUP
Morgantown, West Virginia

Cambridge Springs, Pennsylvania Edinboro Pennsylvania 
$\underline{\text { Awards }}$

2015 “Cup of Distinction” Daily Ritual Cup Show

2011 Functional Ceramics Conference Student Scholarship

Wooster, Ohio

2011 Donna Nicholas Student Scholarship, EUP

Edinboro, Pennsylvania

2011

2nd Place, "Clarion Mug Show"

Clarion, Pennsylvania

Work Experience

2016 Graduate Assistant, West Virginia University

- Teaching

- Studio Maintenance

- Mentoring

2015 Studio Technician, University of Edinboro

Edinboro, Pennsylvania

- Mix slips and glazes

- Fire and help repair kilns

- Assist students, provide guidance

- Develop and refine work to prepare for graduate studies

2014 Studio Assistant for Tara Wilson

- Work/studio-living exchange.

- Clean and maintain studio

- Wood kiln maintenance and wood splitting

- Glaze test and mix glazes

2014 Archie Bray Foundation Clay Biz.

- Mix clay to help support resident artists

Helena, Montana

- Chemical weigh outs

- Resident Assistance as needed

- Pugmill Operation

2013 Campbell's Studios

- Load and unload kilns

- Formulate glazes

2013 Campbell's Pottery Sales Associate

- Pack and ship pottery

- Set up art displays

- Assist with gallery exhibitions

Helena, Montana

West Virginia

Edinboro, Pennsylvania

Edinboro, Pennsylvania

- Clean Studio

- Monitor Kilns

- Process Clay

- Assist in class instruction 